\title{
"Modlitwa dla Marty" - pieśń dwóch rewolucji
}

$\mathrm{W}$

DZIEJACH LUDZKości jest bardzo wiele symboli sprzeciwu, oporu czy protestu. Są to postacie, wydarzenia czy miejsca. Są to też pieśni, specjalna grupa hymnów rewolucji, wyrażających społeczne emocje. Są nie tylko środkami ekspresji, symbolami, ale także specyficznego rodzaju „bronią”, przypominającą o buncie i z tego powodu zwalczaną tak samo jak czołowi działacze opozycji. Jedną z takich pieśni była Modlitwa dla Marty (czes. Modlitba pro Martu), która zwyciężyła w plebiscycie na pieśń aksamitnej rewolucji zorganizowanym w listopadzie 2007 r. przez portal internetowy iDNES.cz'. Uzyskała wówczas ponad 1500 na około 2500 głosów ${ }^{2}$. Pieśń ta pojawiła się w dziejach Czechosłowacji dwa razy: w 1968 i 1989 r. Za każdym razem wiązała się z walką z komunistycznym reżimem i radziecką dominacją. Piosenka ta uczyniła legendą także jej wykonawczynię, która stała się swoistą ikoną najnowszej historii. Niniejszy artykuł ma na celu przedstawienie pokrótce losów ich obu: Modlitwy i Marty.

\section{MARTA}

WYKONAWCZYNI PIEŚNI, Marta Kubišová urodziła się 1 listopada 1942 r. w Czeskich Budziejowicach. Od 1962 r. występowała w teatrze, w 1965 r. poznała Helenę Vondračkovą i Vaclava Neckařa, z którymi trzy lata później stworzyła trio Golden Kids . Została laureatką Złotego Słowika w 1967 r. Po inwazji wojsk Układu Warszawskiego na Czechosłowację, 21 sierpnia 1968 r., wykonała słynny protest song, wspomnianą wyżej „Modlitwę”, co przyczyniło się do zakończenia jej kariery muzycznej w ówczesnym systemie. Nim to się jednak stało, zespół Golden Kids święcił triumfy i koncertował za granicą, a w 1969 r. M. Kubišová otrzymała Złotego Słowika. Kres działalności tria, który na-

\footnotetext{
${ }^{1}$ Jest to portal internetowy stworzony przez czeski dziennik „Mladá Fronta DNES”.

2 „Sametovým“ písním kraluje Modlitba pro Martu, iDNES.cz, 8. listopadu 2007, http://kultura.idnes.cz/sametovym-pisnim-kraluje-modlitba-pro-martu-f3n-/hudba. asp?c=A071107_154114_hudba_kot, 16.08.2010 r.
} 
stąpił 3 marca 1970 r., związany był ze sfabrykowanymi przez czechosłowacką służbę bezpieczeństwa zdjęciami pornograficznymi M. Kubišovej. Napisała ona wówczas listy do V. Neckařa i H. Vondračkovej, w których radziła im rozpoczęcie solowej kariery. Mimo iż obroniła swoje dobre imię przed sądem, nie mogła już więcej zaśpiewać. Reżim uniemożliwił jej podjęcie jakiejkolwiek pracy, trudniła się chałupnictwem. W $1971 \mathrm{r}$. poroniła, a w następnym roku rozstała się z mężem³. Śpiewała w podziemnych wydawnictwach, była też sygnatariuszką Karty 77. W 1981 r. uzyskała pracę jako urzędniczka. Jej pierwszym publicznym wystąpieniem był udział w demonstracji w 40. rocznicę uchwalenia Powszechnej Deklaracji Praw Człowieka w 1988 r. W roku 1989, po blisko 20 latach przerwy ponownie nagrywała w studiu, jednak najbardziej symbolicznym wydarzeniem tego roku był jej udział w demonstracji 21. listopada na Placu Wacława w Pradze. Stojąc u boku Václava Havla, zaśpiewała „Modlitwę dla Marty”, która na powrót stała się hymnem, tym razem właśnie dokonującej się „aksamitnej rewolucji”. Lata dziewięćdziesiąte upływają pod znakiem powrotu do aktywności artystycznej: w 1990 r. miał miejsce pierwszy koncert „Marta w Lucernie”, ponadto M. Kubišova zaangażowała się w adwentowe koncerty charytatywne, rozpoczęła cykl programów „Chcete mě?” (pol. „Chcecie mnie?”), poświęconemu adopcji bezdomnych zwierząt, zagrała także w filmie byłego męża. Ważnym wydarzeniem był ponowny występ tria zespołu Golden Kids w listopadzie 1994 r. w Lucernie. Drugi raz artyści spotkali się w marcu 1995 r. W kolejnych latach M. Kubišová kontynuowała swoją karierę muzyczną.

\section{PRASKA WIOSNA}

TwóRCĄ MUZYKI „Modlitwy dla Marty” był Jindřich Brabec (19332001), znany czeski kompozytor i publicysta, autor popularnego także w Polsce przeboju Heleny Vondračkovej „Malowany dzbanku” (czes. „Malovaný džbánku”). Pieśń, którą skomponował, miała charakter sprzeciwu wobec tzw. normalizacji po 1968 r., jednak wcześniej sam popierał socjalistyczną orientację czeskiej piosnki ${ }^{4}$. Autorem słów był natomiast tekściarz i poeta Petr Rada (1932-2007). Tworzył dla wielu gwiazd czechosłowackiej piosenki w latach sześćdziesiątych XX w., w 1971 r. po odmowie współpracy z bezpieką udał się na emigrację

${ }^{3}$ w 1974 r. ponownie wyszła za mąż, a w 1979 r. urodziła córkę.

${ }^{4}$ Brabec, Jindřich, Český hudební slovník osob a institucí, http://www.ceskyhudebnislovnik.cz/slovnik/index.php?option=com_mdictionary\&action=record_detail\&id=460o\&printable $=1 \&$ userview $=, 23.10 .2010 \mathrm{r}$. 
do Australii, był redaktorem czechosłowackiej gazety. Do Czech wrócił w 1990 r. ${ }^{5}$. W tekście „Modlitwy” wykorzystał motto do utworu Jana Amosa Komenskiego z 1650 r. Testament umierajacej matki jednoty czesko braterskiej (czes. Kšaft umírající matky jednoty bratrské) ${ }^{6}$.

Pieśn po raz pierwszy pojawiła się w ostatnim odcinku popularnego serialu kostiumowego Pieśń dla Rudolfa III (czes. Piseň pro Rudofla III) w sierpniu 1968 r. i nosiła tytuł Modlitwa (czes. Modlitba) Rok później, w nocy z 23 na 24 sierpnia nagrywano ją po raz drugi. Ponieważ M. Kubišová nie mogła przejechać z powodu radzieckiego patrolu, J. Brabec dyktował jej słowa piosenki przez telefon. Nagranie przemyciła w kieszeni swojego płaszcza. Ostatecznie powstały cztery wersje piosenki, jedna z nich znalazła się na płycie piosenkarki Pieśni i ballady (czes. Songy a balady). Zanim została zakazana sprzedała się w nakładzie 80 tysięcy egzemplarzy. Po zakazie z 1970 r. pieśń była puszczana przez Radio Wolna Europa i Głos Ameryki. Sama M. Kubišová śpiewała ją także w prywatnym mieszkaniu swoich przyjaciół, Havlów7.

\section{AKSAmitna REWOLUCJA}

„Modltwwa dla Marty” była tak naprawdę hymnem dwóch rewolucji. Po raz drugi została zaśpiewana bowiem w listopadzie 1989 r. Przez poprzednie dwie dekady była zakazana, a jej wykonawczyni nie miała możliwości nie tylko śpiewania, ale także przez pewien czas zarobienia na swoje utrzymanie. Gdy podpisywała Kartę 77 bardziej niż na polityce skupiona była nad możliwością pracy - po wielu latach otrzymała wreszcie posadę urzędniczki. Nie wierzyła wtedy, że coś się może zmienić. 17 listopada 1989 r. została zaproszona na demonstrację z okazji 50-lecia śmierci Jana Opletala. Nie pojawiła się na niej z powodu choroby córki, dzięki czemu uniknęła brutalnej pacyfikacji

${ }^{5}$ Kam zamizel ten starý song. Petr Rada, Česká Televize, http://www.ceskatelevize.cz/porady/1127325486-kam-zmizel-song/20454215628-petr-rada/, 24.10.2010 r.

${ }^{6}$ „Věřím i já Bohu, že po přejití vichřic hněvu, na hlavy naše uvedeného hříchy našimi, vláda věcí tvých k tobě se zase navrátí, ó lide český!”, J. A. Komenský, Kšaft umírající matky jednoty bratrské, Databáze křestanských děl, http://www.umc.cz/ dkd/dila/_Ksaft_umirajici_matky_Jednoty_Bratrske_9217.HTM, 7.11.2010 r.

${ }^{7}$ B. Štenclová, Prayer for Marta (Modlitba pro Martu), Praha.eu, http://www.praha.eu/jnp/en/extra/Year_68/pop_music/prayer_for_marta_modlitba_pro_martu. html, data dostępu: 2.11.2010, Kubišová o srpnové invazi: Poctivě jsem zavzpomínala, můžu odjet na Šumavu, iDNES.cz, 16. srpna 2008, http://kultura.idnes.cz/kubisova-o-srpnove-invazi-poctive-jsem-zavzpominala-muzu-odjet-na-sumavu-15l-/hudba. asp?c=Ao80815_173404_hudba_jaz, 7.11.2010 r. 
protestu. Kilka dni później, 21 listopada studenci z Petrem Léblem na czele poprosili ją o zaśpiewanie hymnu na Placu Wacława, dokąd zaprowadził ją Ondřej Vetchý. Myślała wówczas, że będzie śpiewać dla kilku osób. Ku swojemu zaskoczeniu Jiři Černý zaprosił ją na balkon Hotelu Melantrich, skąd przemawiał Václav Havel, i poprosił o zaśpiewanie Modlitwy a capella, pierwszy raz od 20 lat. Jak sama wspomina było to dla niej stresująca sytuacja, nie była nawet pewna, czy pamięta słowa słynnej pieśni ${ }^{8}$.

\section{MARTA I POLITYKA}

ZE WZGLĘDU NA OBECNoŚć w czeskiej historii najnowszej, nie tylko kulturalnej, ale i politycznej, M. Kubišová może być postrzegana również przez pryzmat własnych sympatii i kontaktów z politykami. Gdy śpiewała w Golden Kids nie angażowała się w politykę, w owym czasie była sympatyczką Aleksandra Dubčeka, przywódcy praskiej wiosny. Znane jest zdjęcie, na którym piosenkarka wręcza wracającemu z Moskwy politykowi bukiet kwiatów i medalik z aniołem9 . Od lat sześćdziesiątych przyjaźniła się z Václavem Havlem i jego pierwszą żoną, Olgą. Przyszły prezydent Czechosłowacji, a potem Republiki Czeskiej, był ojcem chrzestnym jej córki, Kateřiny ${ }^{10}$. W latach dziewięćdziesiątych M. Kubišova wyrażała poparcie dla Unii Demokratycznej (czes. Demokratická unie, DEU) z uwagi na obecność w jej programie wsparcia dla małych i średnich przedsiębiorców. Ze względu na te sympatie polityczne wzięła udział w jednym ze spotkań wyborczych, na którym się jednak okazało, że nie jest to wiec DEU, ale tzw. „Czwórkoalicji”"

${ }^{8}$ I. Willoughby, Prayer for Marta singer Kubišová recalls dramatic comeback during 1989's Velvet Revolution, Radio Praha, 18.11.2009, http://www.radio.cz/en/section/czechstoday/prayer-for-marta-singer-kubisova-recalls-dramatic-comeback-during-1989s-velvet-revolution, 30.10.2010 r.; D. Vaughan, A song becomes the symbol of the revolution, Radio Praha, 23.07.2009, http://www.radio.cz/en/section/archives/asong-becomes-the-symbol-of-the-revolution, 30.10.2010 r.; B. Kratochvíl, Jak se zpívala „modlitba“, „Lidové Noviny”, 14.11.2009; J. Hůla, Kubišová: Nejsem žádná Johanka z Arku, iDNES.cz, 16. listopadu 2001, http://kultura.idnes.cz/kubisova-nejsemzadna-johanka-z-arku-d78-/hudba.asp?c=A011116_125202_hudba_kne, 7.11.2010 r.

9 T. Poláček, Marta Kubišová: Symbol srpna 1968, iDNES.cz, 21. srpna 2003, http://revue.idnes.cz/marta-kubisova-symbol-srpna-1968-dzv-/lidicky. asp?c=A030821_140905_lidicky_jup, 5.11.2010 r.

${ }^{10}$ Idem, Kubišová: Svýjsem si už odbojovala, iDNES.cz, 5. září 2002, http://kultura. idnes.cz/kubisova-svy-jsem-si-uz-odbojovala-dtq-/hudba.asp?c=A020905_120032_ hudba_brt, 7.11.2010 r.

${ }^{11}$ Była to istniejąca w latach 1998-2002 koalicja czterech partii prawicowych: Obywatelskiej Partii Demokratycznej (ODS), Unii Chrześcijańsko-Demokratycznej-Czeco- 
Piosenkarka poczuła się oszukana i zapowiedziała, że już nie zaangażuje się w politykę ${ }^{12}$. Ona i jej pieśń pojawiły się jednak w polityce ponownie w 2010 r. - tytuł pieśni został wykorzystany w komentarzu do czeskiej kampanii wyborczej w 2010 r., który zamieścił „The Economist” ${ }^{3}$. Sama M. Kubišová poparła ruch „Wymieńcie polityków”, sprzeciwiającego się korupcji i nawołujący do głosowania na małe partie. W krótkim spocie mówiła, iż w czasie mijającej kadencji czuła się jakby mieszkała w „domu wariatów”"14.

Modlitwa dla Marty jest pieśnią ponadczasową, choć wiąże się konkretnymi wydarzeniami i konkretną epoką. Wynika to z uniwersalnego przesłania, pewnej idealnej wizji życia społecznego, życzenia wyrażanego przez ludzi w różnych epokach i w różnych państwach. Szczególną rolę odegrała tutaj wykonawczyni, której życie zdeterminowała ta jedna pieśn. Jej życiorys, przede wszystkim represje, przyjaźń z Václavem Havlem, stały się kolejnym symbolem, choć sama Marta Kubišová nigdy się do polityki nie włączyła. Jej postać stała się swego rodzaju symbolem, wręcz żywym pomnikiem dwóch czechosłowackich rewolucji. Tym samym zarówno hymn, jak i piosenkarka, jako nosicielka jego idei, trochę mimo woli, stały się mitem czy też legendą czeskiej walki o wolność.

\section{SUMMARY}

This paper focuses on the legendary song entitled Prayer for Marta and its performer. It is a history of two revolutions and a famous singer's difficult life. Both were the symbols of changes in Czechoslovakia. Both were absent in a public life as the song was banned and Marta Kubišová couldn't perform. Nowadays, both are the icons of modern Czech history. This article describes how this song was created and sang twice. It also explains who was its author. What is more, Marta 's life and her view on contemporary politics are presented.

słowacka Partia Ludowa (KDU-ČSL), Unii Wolności (US) i Unii Demokratycznej (DEU).

${ }^{12}$ T. Poláček, Kubišová..., op. cit.

13 The song by Marta, „The Economist”, 20.05.2010, http://www.economist. com/node $/ 16167808$ ?story_id $=16167808 \&$ CFID $=135229282 \&$ CFTOKEN $=74570452$, 16.08.2010 r.

${ }^{14}$ Marta Kubišová - VYMĚŇTE POLITIKY!, YouTube, http://www.youtube.com/ watch?v=5SM6pOUxXeI\&feature=youtube_gdata, 6.08.2010 r. 


\section{Nota O AUTORZE}

Marcin Skobrtal [mskobrtal@wp.pl] - doktorant w Zakładzie Studiów Strategicznych Wydziału Nauk Politycznych i Dziennikarstwa UAM. Zainteresowania: nacjonalizm, kwestie narodowościowe, społeczeństwo i historia Dolnego Śląska. 